\title{
Review
}

\section{Political theory and film: From Adorno to Žižek}

Ian Fraser

Rowman \& Littlefield, New York, 2018, viii + 197pp., ISBN: 978-1-78348-164-4

Contemporary Political Theory (2019) 18, S255-S258. https://doi.org/10.1057/s41296018-0239-y; published online 25 June 2018

Film scholarship, from early on, has been caught in the matrix of the political theory of its time. From the early writings of Eisenstein on the dialectical image and Soviet montage theory, to the postwar French criticism found in the Cahiers $d u$ cinéma and the post-1968 English developments in so-called 'screen theory', all the way up to the political debates about the role of theory, Marxism, and psychoanalysis in filmic critiques of ideology and subjectivity in the post-Soviet period, political theory has always seemed to edge its way into the study of cinema. Political theories have often been tied to the aesthetic weighting and visual rhetorics of the image, usefully bringing about tactics for political criticism in areas beyond the cinema. It is with this in mind that political theory has benefitted from film theory, and vice versa. Ian Fraser's Political Theory and Film: From Adorno to Žižek seeks to add and contribute to contemporary efforts in this area.

True to its subtitle, the book examines a range of past and contemporary theorists, including Theodor Adorno, Walter Benjamin, Ernst Bloch, Gilles Deleuze, Alain Badiou, Jacques Rancière, Julia Kristeva, and Slavoj Žižek. Each chapter is devoted to the work of one individual figure, with the core ideas of each theorist being applied to a political interpretation of individual films. For instance, Fraser reads Charlie Chaplin's Monsieur Verdoux through the prism of Theodor Adorno's framework, Woody Allen's more recent Midnight in Paris through Ernst Bloch's, and David Fincher's Fight Club through Julia Kristeva's. Each individual chapter, then, serves as a wonderful and useful introduction, not only to a host of accessible and intriguing films, but also to the core ideas of a set of influential critical theorists.

Fraser begins the book, however, by clarifying what makes possible the application of political theory to film. Political theory, he explains, often and more conventionally applies to theories and questions about the state. But political theory, he says, also importantly addresses questions about power, its constitution, and the role that it plays in society. But political theories of power can often be

(ㄷ) 2018 Macmillan Publishers Ltd., part of Springer Nature. 1470-8914 Contemporary Political Theory Vol. 18, S4, S255-S258 www.palgrave.com/journals 
rather opaque. Therefore, Fraser's stated goal in this book is to help elucidate the core ideas of contemporary political theory by demonstrating its merits through filmic examples. Fraser chose to look, not at political theories, but at the ideas of particular theorists, whom he has selected because of their ties to a particular variety of political criticism on the Left. More specifically, the theorists that he writes about each take up a position with regard to the forms of power and oppression that exist within capitalist society. Each of these theorists has addressed, in one way or another, the prevailing social relations under capitalism. The book is, thus, not about political theory in general; rather, it is a book of critical political theory that also addresses questions about resistance to existing forms of power and oppression. It takes up questions around radical ethics as evinced through the work of the theorists he writes about and the films that he has chosen to interpret. Political Theory and Film is therefore not a work applying a general theory of the political to films in general. On the contrary, it has a specific mission: to critique existing capitalism. The theorists and films studied in the text provide insights into capitalist forms of power and oppression.

In the introductory chapter, Fraser contextualizes the book against four other recent texts that integrate political theory with film criticism. The texts and scholars he cites draw on ties to modern and postmodern political theory. These include the Kantian (or post-Kantian) approach of Michael Shapiro in his book, Cinematic Political Thought (1999), the Humeanism of Davide Panagia in Impressions of Hume (2013), Richard Rushton's post-Marxist writing in The Politics of Hollywood Cinema (2013), and John S. Nelson in Popular Cinema and Political Theory (2013). Fraser cites these texts and provides his own summaries as a brief literature review of the existing field of political film scholarship. Both in the book's introduction and in the conclusion, Fraser spends some time identifying the substance of his own contribution as measured against these texts. This, he stresses, is to examine how the ideas from each of the theorists he studies can be used to examine the selection of films that he has chosen. It is on these individual interpretations of filmic examples, which ultimately introduce readers to the political theories of each individual thinker, that Fraser's book does have merit, and I would recommend it to young undergraduate scholars eager to learn more about the work of the theorists surveyed in this book. The book, in this way, nicely extrapolates what is important and relevant about critical political theory today, using film as an avenue or entry point into the critique of power.

However, I maintain some reservations about this book. On the one hand, it is clearly on the side of critical theory, based, that is, upon the selection of theorists engaged. However, on the other hand, one thing that I find missing is a focused engagement with the cleavages between the scholars surveyed. Fraser appears less concerned with the divides between these thinkers than with an expository exploration of their individual contributions, and therefore his own allegiances to this or that perspective remains somewhat elusive and at times ambiguous. Apart

S256 (c) 2018 Macmillan Publishers Ltd., part of Springer Nature. 1470-8914 Contemporary Political Theory Vol. 18, S4, S255-S258 
from his initial and concluding emphasis on the need for a critical political theory of capitalist forms of power, the specific need for such criticism is never thoroughly unpacked in this book. Therefore the reader is left wondering what is truly at stake in the application of critical theory to film criticism. How does it advance the substantial theory of capitalist forms of power? Rather than explain the need for a critical political theory of capitalist power and oppression (why not of exploitation?), this fact is simply taken as given. However, in light of the period and stakes in which this book has been published-against the background of rising austerity in the post-2008 crisis period, deepening neoliberalism, and the perils of the precariat, for example-providing at the very least a minimal review of this context might have given the book and its purpose an added edge.

Fraser, at times, speaks of the need, or at least the value, of a political theory of film, but, whether intentionally or not, he doesn't address or consider the long and existing history of this work within film and cultural studies. Whereas Rushton's book, for instance, does provide an important historical and theoretical trajectory of post-Althusserian political theory and its influence on film criticism-and, in his critique of theorists, such as Žižek, Rushton is able to more forcefully advance his own political commitments and leanings-this kind of engagement is suspiciously absent in Fraser's text. Since he explicitly advocates a 'political theory of film because it can further a critical stance to the status quo and in particular capitalist relations in their various guises' (p. 175), it would be useful to see how Fraser himself positions his work against the already existing tradition of political film scholarship, apart, that is, from simply providing introductory-albeit highly useful-summaries of critical theorists.

At its best, this book introduces readers to a range of critical political theorists, who have in many cases written on or about film and shows the significance of their ideas for a critical interpretation of film; moreover, the book demonstrates how film criticism contributes to the exposition of core ideas in political theory. It is therefore quite accessible and helpful from a pedagogical standpoint. But I, for one, would be more interested in knowing where Fraser positions himself within the tradition of political and film theory, and where he stands relative to its existing ethical debates.

\section{References}

Nelson, J. S. (2013). Popular cinema and political theory: Idealism and realism in epics, noirs and satires. New York: Palgave Macmillan.

Panagia, D. (2013). Impressions of hume: Cinematic thinking and the politics of discontinuity. Lanham, MD: Rowman \& Littlefield.

Rushton, R. (2013). The politics of hollywood cinema: Popular film and contemporary political theory. New York: Palgrave Macmillan.

(c) 2018 Macmillan Publishers Ltd., part of Springer Nature. 1470-8914 Contemporary Political Theory Vol. 18, S4, S255-S258 S257 
Shapiro, M. J. (1999). Cinematic political thought: Narrating race, nation and gender. Edinburgh: Edinburgh University Press.

Matthew Flisfeder

University of Winnipeg, Winnipeg, MB R3B 2E9, Canada m.flisfeder@uwinnipeg.ca 